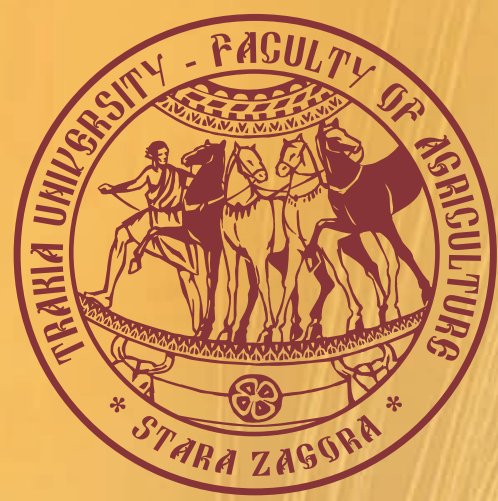

ISSN $1313-8820$ (print)

ISSN $1314-412 X$ (online)

Volume 9 , Number 1

March 2017

\title{
AGRICULTURAL
}

\section{SCIENCE AND TECHNOLOGY}

\section{7}

An International Journal Published by Faculty of Agriculture, Trakia University, Stara Zagora, Bulgaria 


\section{Editor-in-Chief}

Georgi Petkov

Faculty of Agriculture

Trakia University, Stara Zagora

Bulgaria

E-mail: gpetkov@af.uni.sz.bg

\section{Co-Editor-in-Chief}

Dimitar Panayotov

Faculty of Agriculture

Trakia University, Stara Zagora

Bulgaria

\section{Editors and Sections}

\section{Genetics and Breeding}

Tsanko Yablanski (Bulgaria)

Atanas Atanasov (Bulgaria)

Svetlana Georgieva (Bulgaria)

Nikolay Tsenov (Bulgaria)

Max Rothschild (USA)

Ihsan Soysal (Turkey)

Horia Grosu (Romania)

Stoicho Metodiev (Bulgaria)

Bojin Bojinov (Bulgaria)

\section{Nutrition and Physiology}

Nikolai Todorov (Bulgaria)

Peter Surai (UK)

Ivan Varlyakov (Bulgaria)

George Zervas (Greece)

Vasil Pirgozliev (UK)

\section{Production Systems}

Radoslav Slavov (Bulgaria)

Dimitar Pavlov (Bulgaria)

Bogdan Szostak (Poland)

Banko Banev (Bulgaria)

Georgy Zhelyazkov (Bulgaria)

\section{Agriculture and Environment}

Martin Banov (Bulgaria)

Peter Cornish (Australia)

Vladislav Popov (Bulgaria)

Tarek Moussa (Egypt)

\section{Product Quality and Safety}

Stefan Denev (Bulgaria)

Vasil Atanasov (Bulgaria)

Roumiana Tsenkova (Japan)

\section{English Editor}

Yanka Ivanova (Bulgaria)
Scope and policy of the journal

Agricultural Science and Technology /AST/

- an International Scientific Journal of Agricultural and Technology Sciences is published in English in one volume of 4 issues per year, as a printed journal and in electronic form. The policy of the journal is to publish original papers, reviews and short communications covering the aspects of agriculture related with life sciences and modern technologies. It will offer opportunities to address the global needs relating to food and environment, health, exploit the technology to provide innovative products and sustainable development. Papers will be considered in aspects of both fundamental and applied science in the areas of Genetics and Breeding, Nutrition and Physiology, Production Systems, Agriculture and Environment and Product Quality and Safety. Other categories closely related to the above topics could be considered by the editors. The detailed information of the journal is available at the website. Proceedings of scientific meetings and conference reports will be considered for special issues.

\section{Submission of Manuscripts}

There are no submission / handling / publication charges.

All manuscripts written in English should be submitted as MS-Word file attachments via e-mail to editoffice@agriscitech.eu. Manuscripts must be prepared strictly in accordance with the detailed instructions for authors at the website

www.agriscitech.eu and the instructions on the last page of the journal. For each manuscript the signatures of all authors are needed confirming their consent to publish it and to nominate on author for correspondence.

They have to be presented by a submission letter signed by all authors. The form of the submission letter is available upon from request from the Technical Assistance or could be downloaded from the website of the journal. Manuscripts submitted to this journal are considered if they have submitted only to it, they have not been published already, nor are they under consideration for publication in press elsewhere. All manuscripts are subject to editorial review and the editors reserve the right to improve style and return the paper for rewriting to the authors, if necessary. The editorial board reserves rights to reject manuscripts based on priorities and space availability in the journal.

The journal is committed to respect high standards of ethics in the editing and reviewing process and malpractice statement. Commitments of authors related to authorship are also very important for a high standard of ethics and publishing. We follow closely the Committee on Publication Ethics (COPE), http://publicationethics.org/resources/guid elines

The articles appearing in this journal are indexed and abstracted in: DOI, EBSCO Publishing Inc. and AGRIS (FAO).

The journal is accepted to be indexed with the support of a project № BG051PO0013.3.05-0001 "Science and business" financed by Operational Programme "Human Resources Development" of EU. The title has been suggested to be included in SCOPUS (Elsevier) and Electronic Journals Submission Form (Thomson Reuters).

The journal is freely available without charge to the user or his/her institution. Users can read, download, copy, distribute, print, search, or link to the full texts of the articles, or use them for any other lawful purpose, without asking prior permission from the publisher or the author.

This issue is printed with the financial support by Contract No DNP 0521/20.12.2016, financed from Fund 'Scientific Research' grant Bulgarian scientific Periodicals.

\section{Address of Editorial office:}

Agricultural Science and Technology Faculty of Agriculture, Trakia University

Student's campus, 6000 Stara Zagora

Bulgaria

Telephone: +35942699330 $+35942699446$

www.agriscitech.eu

Technical Assistance:

Nely Tsvetanova

Telephone: +359 42699446

E-mail:editoffice@agriscitech.eu 


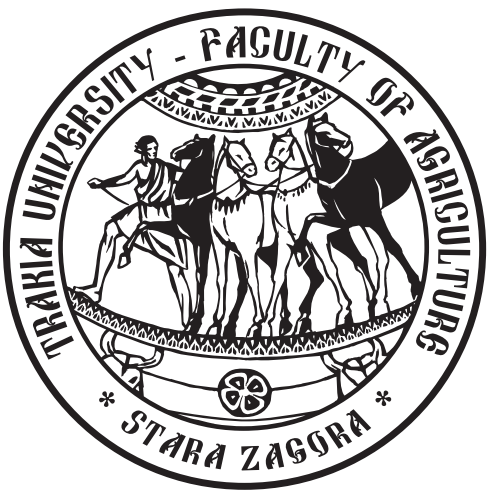

AGRICULTURAL

SCIENCE AND TECHNOLOGY

\section{7}

An International Journal Published by Faculty of Agriculture,

Trakia University, Stara Zagora, Bulgaria 


\title{
Hot-water treatment of gladiolus cormels for control of corm-borne fungal diseases
}

\author{
S. Bistrichanov1, T. Vatchev² Z. Avramov* \\ ${ }^{1}$ University of Forestry, 10 Kliment Ohridski, 1797 Sofia, Bulgaria \\ ${ }^{2}$ Institute of Soil Science, Agrotechnologies and Plant Protection, 35 Panayot Volov, 2230 Kostinbrod, Bulgaria
}

(Manuscript received 18 May 2016; accepted for publication 23 January 2017)

\begin{abstract}
A hot-water treatment was used successfully to obtain pathogen-free planting stock from various plants to control some diseases including gladiolus. The objective of this study was to evaluate the effect of hot-water treatments in terms of damaging gladiolus, concerning sprouting and leading to crop loses. Cormels of two gladiolus cultivars, Oscar and Amsterdam, were used for each treatment (temperature x time period) and were immersed in water baths with hot water at $20^{\circ} \mathrm{C}$ (as control), $45^{\circ} \mathrm{C}, 50^{\circ} \mathrm{C}, 55^{\circ} \mathrm{C}$ and $60^{\circ} \mathrm{C}$ for different treatment periods 10,20 and 30 min and were planted in pots $(\mathrm{d} 10 \mathrm{~cm})$ filled with sterile nutrient substrate (peat:soil:perlite in ratio 3:1:0.5). Three replicate pots each containing 10 cormels were used per treatment. The results showed that the increase of the temperature and the extension of exposition duration reduced significantly the percentage of the sprouting plants from both cultivars - more than $80 \%$ at $55^{\circ} \mathrm{C} / 20 \mathrm{~min}$, and Oscar was more resistant to this treatment regime. For phytosanitary purposes two treatment options were considered as nondamaging $-45^{\circ} \mathrm{C}$ for $30 \mathrm{~min}$ or $50^{\circ} \mathrm{C}$ for $20 \mathrm{~min}$, wherein the resulting plants showed approximately $90 \%$ sprouting. It was concluded that for successful disease control specific hot-water treatment regimes should be established for every particulargladiolus cultivar.
\end{abstract}

Keywords: gladiolus, hot-water treatment, sprouting

\section{Introduction}

Prevention of diseases caused by plant pathogens is an important element of the integrated pest management. This approach is widely applied to many crops, including flowers. The main approach is to decrease the amount of the initial inoculum of the potential pathogenic organism and thus to minimize the risk for future production.

Thermotherapy is one of the oldest techniques used for killing the pathogen structures in seed or any other form of planting material. This method is considered simple to implement, easy to use and does not require consumption of high cost resources. Different variations like Soaking in Hot Water, Hot Air Treatment, Vapor-Heat Treatment, and their derivates - Soaking in Hot Solution (some chemicals have been added to treatment water); Spraying Hot Water and Microwave Treatment have been applied for treatment of seeds and other plant parts (Grondeau et al., 1994). Such approach was first applied against fusarium rot of gladiolus, wilt, or yellows in California in 1909 (Pryal, 1909).

Treatment with hot water before planting $\left(57^{\circ} \mathrm{C} / 30\right.$ minutes) is a basic method (Magie 1956; Roistacher et al., 1957; Forsberg 1961; Millholand and Aycock 1965; Bald et al., 1971; Hsieh 1985; Kohen et al., 1990 and etc.). Such an approach has been applied in the modern, ecologically benign plant protection systems either alone or in combination with other protection methods (Tripathi et al., 2013).

Fungus Fusarium oxysporum var. gladioli /Massey/ causing fusarium rot in gladiolus was reported for the first time in Bulgaria in 1940 by Hristova (1947). The thermotherapy data on the use and effect on the physiological status of plants of gladioli in our country are very scarce and generally unknown.

The purpose of this study was to determine the effects of treatment with high temperatures for different duration on

*e-mail: zhelu.avramov@gmail.com subsequent development of two selected gladiolus varieties.

\section{Material and methods}

Externally healthy cormels of gladiolus cultivars Oscar and Amsterdam $(\mathrm{d} 0.5-1.0 \mathrm{~cm})$, with removed outer skin, were used for experimental purposes. They were immersed in water baths with sterile hot water at $20^{\circ} \mathrm{C}$ (as control), $45^{\circ} \mathrm{C}, 50^{\circ} \mathrm{C}, 55^{\circ} \mathrm{C}$ and $60^{\circ} \mathrm{C}$ for different treatment periods $-10,20$ and $30 \mathrm{~min}$. After drying, they were planted in pots $(\mathrm{d} 10 \mathrm{~cm})$ filled with sterile nutrient substrate (peat:soil:perlite in ratio 3:1:0.5) with approximate weight of $570 \mathrm{~g}$.

Three replicate pots, each containing 10 cormels, were used for each treatment. The percentage of germination of the planted gladiolus plant was observed and reported during a period of 30 days. The results were statistically handled and summarized with ANOVA program.

\section{Results and discussion}

The results from our preliminary studies showed that in Bulgaria fungi of the genus Fusarium, which infected gladiolus plants and other species representatives of the botanical Family Iridaceae belonged to two species Fusarium oxysporum (Massey) WC Snyder \& HN Hansen and Fusarium moniliforme J. Sheld. and the existence of a population of pathogens with different specialization was found. The temperature range of development was between $5^{\circ} \mathrm{C}$ to $36^{\circ} \mathrm{C}$, with optimal temperature of $26^{\circ} \mathrm{C}$. The other values to $45^{\circ} \mathrm{C}$ and $50^{\circ} \mathrm{C}$ affected the infection (i.e. colony forming units - spores and particles of mycelium) as reduction or termination of viability (Bistrichanov, 2007).

The pathogens were located on the surface and inside the 
tissues of vegetative propagation material (bulbs and cormels). Therefore, in order to inactivate them, they had to be treated at higher temperatures than their ecological maximum. During this procedure it was likely to experience a problem with host plant like a component of the pathological system, namely with violating its reproductive qualities.

Therefore, at the use of thermotherapy on gladiolus (or other flowering bulbs) a balance between the effect on the viability of the pathogen and the reduction of the germination of the respective propagation material should be given. For this purpose, we should find the correlation between these two main factors - duration and temperature value of the thermotherapy.

The experimental dates showed us that germination in the control variant was delayed approximately a week compared with the others (Figure 1). Our suggestion was that it was due to a physiological response to the suffered shock. When the heat stress was confirmed, the plants synthesized group specific proteins called heat shock proteins (Hsp) and the period of rest was interrupted (Ginzburg and Salomon, 1986).

With increase of the exposure time and temperature, the values of sprouting decreased. The results showed that the propagation material lost 80 to $100 \%$ from its qualities even at the variant of treatment $-55^{\circ} \mathrm{C}$. The Oscar variety was more thermally stable, while in that of $60^{\circ} \mathrm{C}-20 \%$ germination was reported in only two of the three repeats (Figure 1).

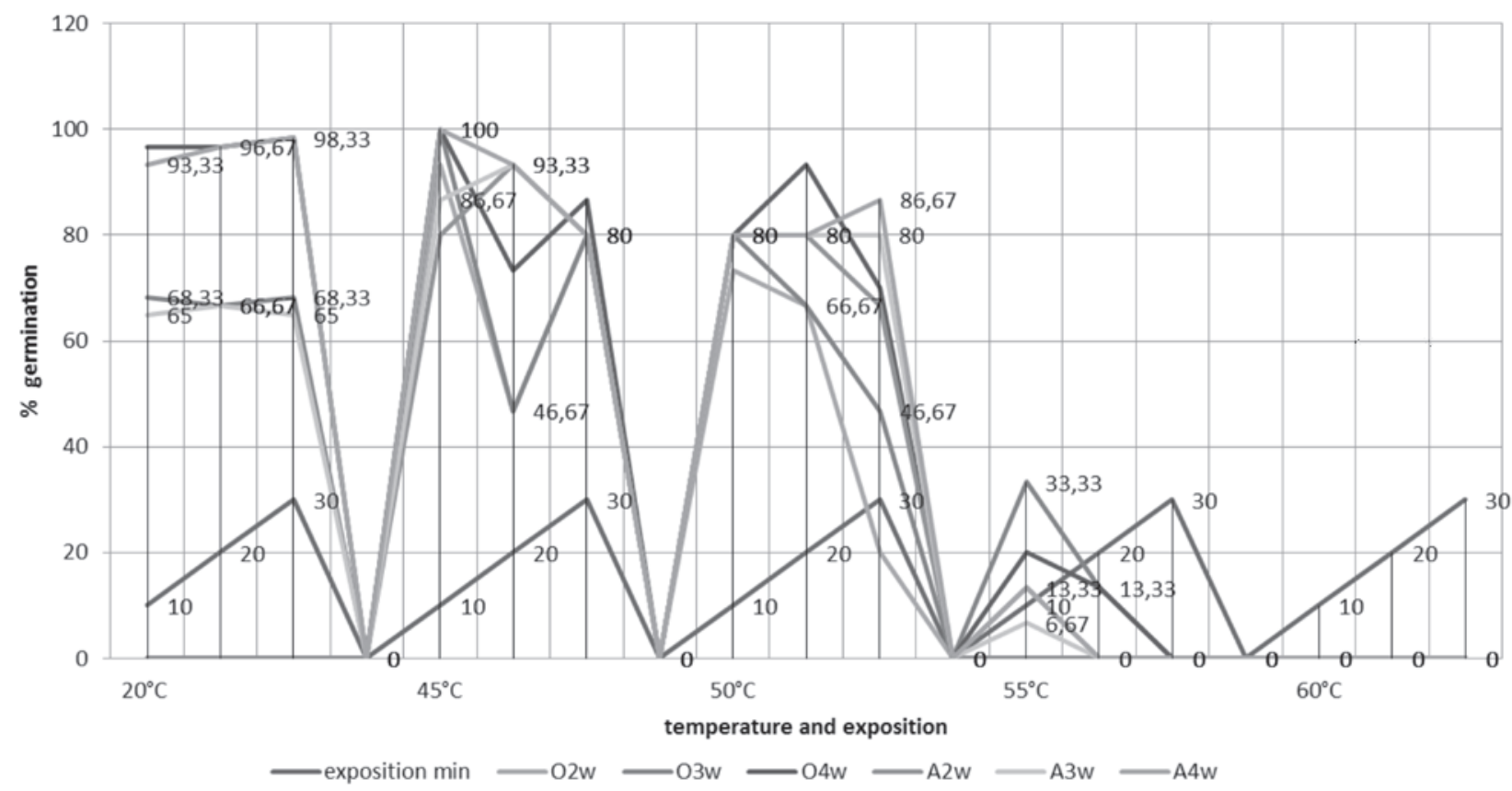

Figure 1. Sprouting tendency of two gladiolus cultivars (cv. Oscar and cv. Amsterdam) expressed as percentage after hot-water treatments before planting

Table 1. Total sprouting of two gladiolus cultivars (cv. Oscar and cv. Amsterdam) in expressed as percentage after hot-water treatments

\begin{tabular}{|c|c|c|c|c|c|}
\hline \multirow{2}{*}{ Temperature } & \multirow{2}{*}{$\begin{array}{l}\text { Exposition/ } \\
\text { Replications }\end{array}$} & \multicolumn{4}{|c|}{ cv. Oscar/Amsterdam - \% } \\
\hline & & $1^{\text {st }}$ replication & $2^{\text {nd }}$ replication & $3^{\text {th }}$ replication & average \\
\hline \multirow[t]{3}{*}{$20^{\circ} \mathrm{C}$} & $10 \mathrm{~min}$ & $100 / 100$ & $100 / 93$ & $100 / 92$ & $100 / 98.33$ \\
\hline & $20 \mathrm{~min}$ & $100 / 100$ & $100 / 90$ & $90 / 90$ & $96.67 / 93.33$ \\
\hline & $30 \mathrm{~min}$ & $80 / 78$ & $60 / 67$ & $50 / 50$ & $63.33 / 65$ \\
\hline \multirow[t]{3}{*}{$45^{\circ} \mathrm{C}$} & $10 \mathrm{~min}$ & $100 / 80$ & $100 / 80$ & $100 / 100$ & $100 / 86.67$ \\
\hline & $20 \mathrm{~min}$ & $100 / 100$ & $40 / 100$ & $80 / 80$ & $73.33 / 93.33$ \\
\hline & $30 \mathrm{~min}$ & $60 / 60$ & $100 / 80$ & $100 / 100$ & $86.66 / 80$ \\
\hline \multirow[t]{3}{*}{$50^{\circ} \mathrm{C}$} & $10 \mathrm{~min}$ & $60 / 80$ & $80 / 80$ & $100 / 80$ & $80 / 80$ \\
\hline & $20 \mathrm{~min}$ & $80 / 60$ & $100 / 100$ & $80 / 80$ & $86.66 / 80$ \\
\hline & $30 \mathrm{~min}$ & $80 / 80$ & $60 / 100$ & $70 / 80$ & $70 / 86.67$ \\
\hline \multirow[t]{3}{*}{$55^{\circ} \mathrm{C}$} & $10 \mathrm{~min}$ & $0 / 0$ & $20 / 40$ & $40 / 0$ & $20 / 13.33$ \\
\hline & $20 \mathrm{~min}$ & $0 / 0$ & $20 / 0$ & $20 / 0$ & $13.33 / 0$ \\
\hline & $30 \mathrm{~min}$ & $0 / 0$ & $0 / 0$ & $0 / 0$ & $0 / 0$ \\
\hline $60^{\circ} \mathrm{C}$ & $10 \mathrm{~min}$ & $0 / 20$ & $0 / 0$ & $0 / 20$ & 0/13.33 \\
\hline
\end{tabular}


To confirm both influence of the two factors - time and temperature, the final data from the experiment for both varieties was handled by package Anova with confidence interval of $p<0.05$. The results showed the validity of the hypothesis that increasing the temperature and time of exposure had a negative effect on the percentage of sprouted cormels of the studied gladiolus varieties. According to the obtained values Fcrit $>\mathrm{F}$ and rejecting the null hypothesis for Oscar ( $F-1.413223$, F crit -3.554557$)$ and Amsterdam variety ( $F-1.207792, F$ crit-3.738892).

For phytosanitary purposes two treatment options were considered as non-damaging for gladiolus cormels according to temperature/exposition time $-45^{\circ} \mathrm{C}$ for $30 \mathrm{~min}$ or $50^{\circ} \mathrm{C}$ for $20 \mathrm{~min}$. Both variants showed approximately $90 \%$ sprouting after HWT.

The experiment showed that the different gladiolus varieties had different thermal stability. Amsterdam variety had a higher one than the Oscar variety and did not lose completely its vitality even subjected to short-term impact of temperature of $60^{\circ} \mathrm{C}$ (Table 1).

\section{Conclusion}

The results of this study show that two hot-water treatment options could be considered as non-damaging for gladiolus cormels, namely temperature of $45^{\circ} \mathrm{C}$ for $30 \mathrm{~min}$ or $50^{\circ} \mathrm{C}$ for $20 \mathrm{~min}$. For successful disease control specific hot-water treatment regimes should be established for every particular gladiolus cultivar.

\section{References}

Catherine G, Samson R and Sands Dr DC, 1994. A Review of Thermotherapy to Free Plant Materials from Pathogens, Especially Seeds from Bacteria. Critical Reviews in Plant Sciences, 13, 57-75.

Christova E, 1947. Gladiolus - cultivation, diseases, pests and control. Sofia, $47(\mathrm{Bg})$.

Bald JG, Suzuki T and Doyle A, 1971. Pathogenicity of Fusarium oxysporum to Easter lily, narcissus and gladiolus. Annals of Applied Biology, 67, 331-342.

Bistrichanov S, 2007. Investigation over fusariosis (Fusarium spp.) on flowers from Iridaceae family in Bulgaria. Thesis for PhD, Sofia (Bg).

Forsberg JL, 1961. Hot water treatment and chemical treatment of Illinois grown gladiolus cormels. Biol. Notes, Illinois Natural History Survey, 43,1-12.

Ginzburg Ch and Salomon R, 1986. The Effect of Dormancy on the Heat Shock Response in Gladiolus Cormels. Plant Physiology, 81, 259-267.

Hsieh S, 1985. Ecology and control of Gladiolus Fusarium Wilt. Plant Protection bulletin, Taiwan, 27, 247-256.

Kohen A, Barzilay A and Vigodsky-Haas H, 1990. Hot water treatment tolerance in gladiolus cormels and their state of dormancy. Acta Horticulturae 266, Flower Bulbs, 495-503.

Magie R, 1956. Hot water treatment for controling gladiolus cormborne pathogens. Phytopathology, 41, 943.

Millholand RD and Aycock R, 1965. Propagation of disease-free gladiolus from hot water treated cormels in Southern North Carolina. Toch. Bull, N.C. Agricultural Experiment Station, 168, 15.

Pryal WA, 1909. Diseases of gladioli. Rural Newyorker, 68,1009. Roistacher CN, Baker KF and Bald JG, 1957. Hot water treatment for gladiolus cormels for eradication of Fusarium oxysporum $\mathrm{f}$. gladioli. Hilgardia, 26, 659-684.

Tripathi A, Sharma N, Sharma V and Alam A, 2013. Integrated Eco-friendly Management of Fusarium Corm Rot and Yellows by Sowing hot Water, UV-C and/or Essential Oil Treated Gladiolus Corms in Soil Solarized and/or Essential Oil Fumigated Experimental Fields. International Journal of Horticultural \& Crop Science Research, ISSN 2249-4243, 3, 51-63. 


\section{Review}

Antimicrobial activity of Lactobacillus acidophilus against pathogenic and food spoilage microorganisms: A review

T. Dinev, G. Beev, S. Denev, D. Dermendzhieva, M. Tzanova, E. Valkova

\section{Genetics and Breeding}

Heterosis and degrees of dominance of grain yield and grain yield elements in maize hybrids in different groups of ripeness

M. Ilchovska

Use of recurrent selection of early flowering in late maize synthetic population. Results of second cycle of breeding.

N. Petrovska, V. Valkova

Productivity and adaptability of new genotypes field pea (Pisum sativum L.) cultivated under environmental condition of Southern Romania

R. Sturzu, A. M. Ene, Cr. Melucă, J. M. Cojocaru

Nitrogen uptake and expense in durum wheat depending on genotype and nitrogen fertilization

G. Panayotova, M. Almaliev, S. Kostadinova

\section{Nutrition and Physiology}

Haematological investigations upon acute intoxication with carbofuran in dogs

R. Binev, I. Valchev, R. Russenov, Y. Nikolov

\section{Production Systems}

Phytosanitary status and yield of kamut (Triticum turgidum polonicum L.) grown in organic and biodynamic farming

V. Maneva, D. Atanasova, T. Nedelcheva

Hot-water treatment of gladiolus cormels for control of corm-borne fungal diseases

S. Bistrichanov, T. Vatchev, Z. Avramov

Productivity of common wheat (Triticum aestivum L.) grown after various predecessors and nitrogen fertilization rates

M. Gerdzhikova

\section{Agriculture and Environment}


Screening of cucurbitaceous rootstocks against root-knot nematodes (Meloidogyne spp.) and soilborne pathogens (Fusarium spp. and Pythium spp.)

V. Yankova, D. Markova, N. Velkov, S. Masheva

Animal hygiene assessment of microclimate in semi open free-stall barns for dairy cows

D. Dimov, Ch. Miteva, I. Marinov, Zh. Gergovska, T. Penev, A. Enchev

Product Quality and Safety

Accumulation of astaxanthin and canthaxanthin in muscle tissues of Rainbow trout (Oncorhynchus mykiss W.) fed with xanthophyll supplemented feed

M. Tzanova

Chemical composition and technological characteristics of wines from red grape varieties, selected in Bulgaria

V. Haygarov, T. Yoncheva, Z. Nakov, M. Ivanov, D. Dimitrov 


\section{Instruction for authors}

\section{Preparation of papers}

Papers shall be submitted at the editorial office typed on standard typing pages (A4, 30 lines per page, 62 characters per line). The editors recommend up to 15 pages for full research paper ( including abstract references, tables, figures and other appendices)

The manuscript should be structured as follows: Title, Names of authors and affiliation address, Abstract, List of keywords, Introduction, Material and methods, Results, Discussion, Conclusion, Acknowledgements (if any), References, Tables, Figures.

The title needs to be as concise and informative about the nature of research. It should be written with small letter /bold, 14/ without any abbreviations.

Names and affiliation of authors The names of the authors should be presented from the initials of first names followed by the family names. The complete address and name of the institution should be stated next. The affiliation of authors are designated by different signs. For the author who is going to be corresponding by the editorial board and readers, an E-mail address and telephone number should be presented as footnote on the first page. Corresponding author is indicated with *.

Abstract should be not more than 350 words. It should be clearly stated what new findings have been made in the course of research. Abbreviations and references to authors are inadmissible in the summary. It should be understandable without having read the paper and should be in one paragraph.

Keywords: Up to maximum of 5 keywords should be selected not repeating the title but giving the essence of study.

The introduction must answer the following questions: What is known and what is new on the studied issue? What necessitated the research problem, described in the paper? What is your hypothesis and goal?

Material and methods: The objects of research, organization of experiments, chemical analyses, statistical and other methods and conditions applied for the experiments should be described in detail. A criterion of sufficient information is to be possible for others to repeat the experiment in order to verify results.

Results are presented in understandable tables and figures, accompanied by the statistical parameters needed for the evaluation. Data from tables and figures should not be repeated in the text. Tables should be as simple and as few as possible. Each table should have its own explanatory title and to be typed on a separate page. They should be outside the main body of the text and an indication should be given where it should be inserted.

Figures should be sharp with good contrast and rendition. Graphic materials should be preferred. Photographs to be appropriate for printing. Illustrations are supplied in colour as an exception after special agreement with the editorial board and possible payment of extra costs. The figures are to be each in a single file and their location should be given within the text.

Discussion: The objective of this section is to indicate the scientific significance of the study. By comparing the results and conclusions of other scientists the contribution of the study for expanding or modifying existing knowledge is pointed out clearly and convincingly to the reader. Conclusion: The most important consequences for the science and practice resulting from the conducted research should be summarized in a few sentences. The conclusions shouldn't be numbered and no new paragraphs be used. Contributions are the core of conclusions. References:

In the text, references should be cited as follows: single author: Sandberg (2002); two authors: Andersson and Georges (2004); more than two authors: Andersson et al.(2003). When several references are cited simultaneously, they should be ranked by chronological order e.g.: (Sandberg, 2002; Andersson et al., 2003; Andersson and Georges, 2004).

References are arranged alphabetically by the name of the first author. If an author is cited more than once, first his individual publications are given ranked by year, then come publications with one co-author, two co-authors, etc. The names of authors, article and journal titles in the Cyrillic or alphabet different from Latin, should be transliterated into Latin and article titles should be translated into English. The original language of articles and books translated into English is indicated in parenthesis after the bibliographic reference $($ Bulgarian $=\mathrm{Bg}$, Russian $=\mathrm{Ru}$, Serbian $=\mathrm{Sr}$, if in the Cyrillic, Mongolian =
Mo, Greek = Gr, Georgian = Geor., Japanese $=\mathrm{Ja}$, Chinese $=\mathrm{Ch}$, Arabic $=\mathrm{Ar}$, etc.)

The following order in the reference list is recommended:

Journal articles: Author(s) surname and initials, year. Title. Full title of the journal, volume, pages. Example:

Simm G, Lewis RM, Grundy B and Dingwall WS, 2002. Responses to selection for lean growth in sheep. Animal Science, 74, 39-50

Books: Author(s) surname and initials, year. Title. Edition, name of publisher, place of publication. Example:

Oldenbroek JK, 1999. Genebanks and the conservation of farm animal genetic resources, Second edition. DLO Institute for Animal Science and Health, Netherlands.

Book chapter or conference proceedings: Author(s) surname and initials, year. Title. In: Title of the book or of the proceedings followed by the editor(s), volume, pages. Name of publisher, place of publication. Example:

Mauff G, Pulverer G, Operkuch W, Hummel K and Hidden C, 1995. C3variants and diverse phenotypes of unconverted and converted C3. In: Provides of the Biological Fluids (ed. $\mathrm{H}$. Peters), vol. 22, 143-165, Pergamon Press. Oxford, UK.

Todorov N and Mitev J, 1995. Effect of level of feeding during dry period, and body condition score on reproductive performance in dairy cows, $I^{\text {th }}$ International Conference on Production Diseases in Farm Animals, September 11-14, Berlin, Germany.

Thesis:

Hristova D, 2013. Investigation on genetic diversity in local sheep breeds using DNA markers. Thesis for PhD, Trakia University, Stara Zagora, Bulgaria, (Bg).

The Editorial Board of the Journal is not responsible for incorrect quotes of reference sources and the relevant violations of copyrights.

\section{Animal welfare}

Studies performed on experimental animals should be carried out according to internationally recognized guidelines for animal welfare. That should be clearly described in the respective section "Material and methods". 


\section{AGRICULTURAL \\ SCIENCE AND TECHNOLOGY}

Volume 9, Number 1 March 2017
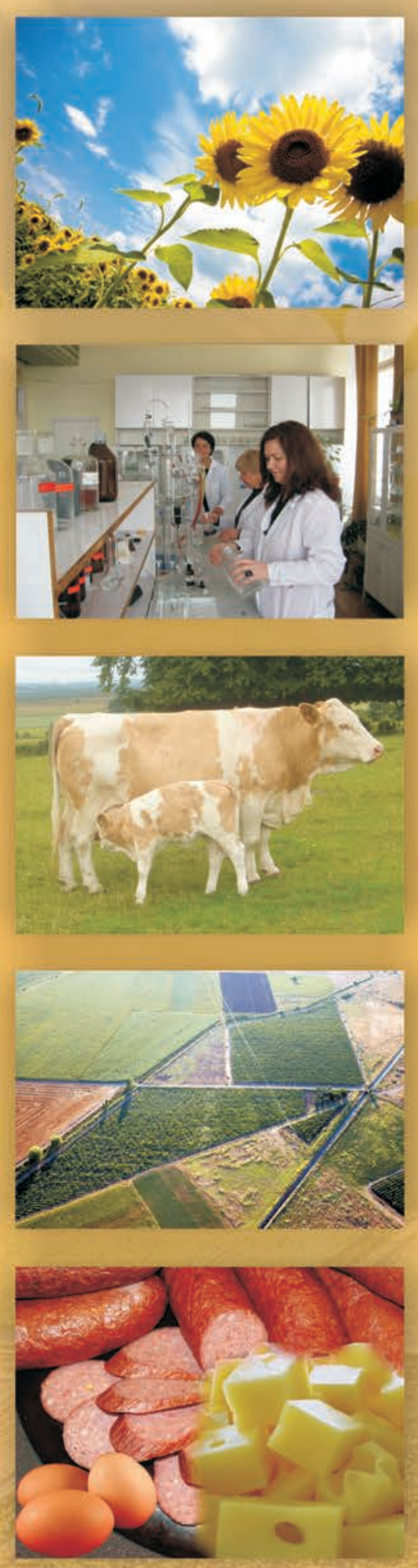

Journal web site: 